\title{
Physical education and sport teachers' organizational democracy perceptions
}

\author{
Enes ISIKGOZ, Melike ESENTAS, Nevzat DINCER
}

School of Phsical Education and Sports, Batman University, Batman, Turkey.

Address Correspondence to N. Dincer, e-mail: nevzatdincer@gmail.com

\begin{abstract}
The purpose of this research was to analyze the physical education and sport teachers' perceptions about organizational democracy. The research group consisted of 191 physical education and sport teachers. The research data were collected by "The Organizational Democracy Scale". In the analysis of data, descriptive statistics, Mann Whitney-U and Kruskall Wallis-H tests were used. According to the relevant findings, the physical education and sport teachers' organizational democracy perceptions were positive in the sub-dimensions of participation-criticism, transparency, justice, equality and accountability but not high, the teachers' organizational democracy perceptions did not significantly vary in gender, assigned school type, marital status and education background variables, in some sub-dimensions they significantly differed in assigned geographical region and seniority variables.
\end{abstract}

Keywords: High school, organizational democracy, physical education and sport, secondary school, teacher.

\section{INTRODUCTION}

In historical process the education case has become foremost in developing, keeping pace with changes and developments for societies. Because education is an action field which makes an individual social and changes him, in this way, education organizations require to be managed within a rational understanding. The most valuable creature education organizations have is human resource assigned at different types and classes of educational services. Human resource has a key role in succeeding educational targets (39). The most important human resource in education organizations is teachers who spend most of their time in managing to teach as professional persons (15). Undoubtedly, success of education organizations depends on performance by teachers at this point. Because performance which has primary importance for organizations, may be favourable like performance shown by staff (9). Many factors affect workers' performance. From these factors, organizational democracy which involves democratic attitudes and behaviours at the forefront, is claimed to increase workers' performance $(28,36$, 43).
Organizational democracy, described as participating in common organization and management for organization members (54), civilizing workplaces (10), attending in managerial power usage for organization workers (27), basically includes equality, participation, discussion and consensus, support for shared organizational values and respect for common values of humanity (11).Participating in decisions, being involved in managerial activities and making common decisions while determining organizational strategies for workers in an organization are fundamental issues of organizational democracy (12). According to this, organizations whichin power and responsibility are largely transferred and workers are organized as selfmanaging units, proceedings for self-thinking, making judgements, making choice and getting into action become legal, are democratic organizations (4).

The dimensions (items) of organizational democracy are ranked as participation-criticism, transparency, justice, equality and accountability (22). Participative management practices, described as involving in all decision processes for workers (directly or via their representatives) (22), affecting decisions by persons, managing citizens about themselves directly or indirectly (52), are indispensable principles of organizational 
democracy (54). Because workers have the right to comment on management by means of taking part in decisions and have opportunities for developing themselves and displaying their abilities within a structure supported with an effective communication and information share environment and education activities, these describe developed organization structures in the framework of organizational democracy (4). Criticism reflects evaluating policies and procedures, works and proceedings, and expressing evaluations by workers at each level (21). Workers' opinions are given importance in enterprises where participation and criticism are encouraged and decisions are taken on a common idea everybody comes to a mutual understanding on (7).

The transparency dimension of organizational democracy can be described as learning and following all aspects of works and proceedings, taken decisions by the relevant ones (21), providing direct information flow about management practices to managed ones (48), allowing others to analyze persons' opinions and actions (50). The justice dimension of organizational democracy is rules and social norms presented by interaction between individuals and (21). In other words, organizational justice is described as regarding competence in an organization, creating prize norms, giving fee based on workers' performance and providing fair income distribution (55). Justice is a really significant issue in fulfilling with workers' personal satisfaction and meeting organizational functions actively (18).

The equality dimension of organizational democracy is described as ensuring legal rights to be used by everyone, having same rights and advantages by everyone (21). Equality involves not exposing individuals to discrimination about issues such as religion, language, race, gender, world view and having equal opportunities to acquire same rights in all individuals (33). The accountability dimension can be described as making explanations to another authority because of a person doings or not doings or being unable to do (2). Because accountability requires to make a statement, research about answers, interrogate, correct mistakes and accept final applicable sanctions (20).

Organizational democracy perception also fosters organizational citizenship behaviours (22). Especially when work life is made democratic in public institutions, members' communication skills and job satisfaction increase, these provide more creative solutions for common problems (46). In democratic society valid political system and value philosophy are based on "human center" and its requirements are fulfilled with education institutions. In such a society the aim of education is to make the world more liveable for people (41). As an organization, having democratic features for school environment considerably affects teacher and student success, lets teachers and students' democratic attitudes and behaviours develop (24). In this way, a democratic working environment is formed in school organizations, teachers' work productivity and creativity increase, it contributes to democratize school environment (8).

Workers' behaviours and attitudes have great importance in the dimensions of participationcriticism, transparency, justice, equality and accountability at school organizations. A large participation is expected for creating management and policy in democratic schools. When not only boards, commissions, teachers and administrators across the school but also students, parents and other members of school society participate in decision process and do activities, democracy culture is supported in curriculum program (49). Administrators' interaction with teachers has a vital role to create confidence culture in an organization. Making course distributions in schools, making extracurricular assignments, taking teachers' opinions without making discrimination when searching for solutions oriented at any problem, displaying behaviours and attitudes to teachers by school administrators, telling teachers about what happens at school clearly without concealing are necessary practice samples for confidence climate in education organizations (5). The aim of this study was to analyze the physical education and sport teachers' organizational democracy perceptions. Towards this aim, these questions were seeked answers; 1) at which level the physical education and sport teachers' organizational democracy perceptions are? 2) Do the physical education and sport teachers' organizational democracy perceptions change in accordance with gender, assigned school type, assigned geographical region, marital status, education background and professional seniority?

\section{MATERIALS \& METHODS}

The research group consisted of 191 volunteer physical education and sport teachers including 119 males and 72 females. By using google docs infrastructure service, data collection form was opened to the teachers' usage online, the teachers were required to tick their opinions in this form via 
announcements from various social media tools. Between the dates 10.04.2017-31.06.2017 the system was open, the filled forms between these dates were evaluated.

The research data were collected by "The Organizational Democracy Scale" developed by Geçkil \& Tikici (22). The scale comprised of five subdimensions and total 28 items. The scale involved the items numbered 1-8 in the "Participation-Criticism" sub-dimension, 9-14 in the "Transparency" subdimension, 15-19 in the "Justice" sub-dimension, 2025 "Equality" sub-dimension, 26-28 in the Accountability" sub-dimension. The scale was of 5 point likert type, the responses were pointed as $1=$ Certainly Disagree, 2=Disagree, 3= Indecisive, 1=Agree and 5=Certainly Agree. The 21st and 23rd items of the scale were opposite expressions, while assessing the scale points, the points were inverted as $5=1,4=2,3=3,2=4$, and $1=5$.

The lowest point from the scale was 28 and the highest point was 140 . When the points from the scale went up, the organizational democracy perception rose. According to the reliability analysis results of the researches, the Cronbach Alpha reliability coefficients were between .74-.95 in the subdimensions of the scale, .95 for the whole scale. In this study, the Cronbach Alpha reliability coefficients were between .77-.88 in the sub-dimensions of the scale, .91 for the whole scale.
In the analysis of data, the only sample, Kolmogorow Smirnov normality test was firstly applied to see whether data showed a normal distribution, the test indicated that any normal distribution was not observed in its sub-dimensions and in total $(\mathrm{z}=, 187 ; \mathrm{p}<.05)$ (Table 1$)$. In this scope, when compared the participants' organizational democracy perceptions to their demographical features, Mann Whitney-U and Kruskall Wallis-H tests from the non-parametrical tests were used. The descriptive statistics were utilised in determining the demographical features and assessing the responses to the scale. In the determination of group value interval of the scale; the formula " $a=$ Range/Relevant Group Number" was used. Accordingly, the group interval was determined as Certainly Agree 5.00-4.20, Agree 4.19-3.40, Indecisive 3.39-2.60, Disagree 2.591.80, Certainly Disagree 1.79-1.00. Data were interpreted based on the value $\mathrm{p}<.05$.

\section{RESULTS}

In this section, the distributions about the participant physical education and sport teachers' demographical information and the teachers' organizational democracy perceptions were determined and then it was studied whether the teachers' perceptions changed in accordance with variables such as gender, assigned school type, regions, marital status, education background and seniority. At Table 1, the distributions about the teachers' demographical features were given.

Table 1. Kolmogorow Smirnov Test results applied for seeing whether data showed a normal distribution.

\begin{tabular}{lccccccc}
\hline & & Participation/Criticism & Transparency & Justice & Equality & Accountability & Total \\
\hline $\mathrm{N}$ & & 191 & 191 & 191 & 191 & 191 & 191 \\
Normal Parameters & Mean & 29.14 & 22.35 & 18.73 & 23.06 & 11.87 & 104.93 \\
& SD & 8.02 & 4.10 & 3.39 & 2.246 & 9.60 & 15.81 \\
$\mathrm{z}$ & & .177 & .483 & .493 & .458 & .490 & .187 \\
$\mathrm{p}$ & & .000 & .000 & .000 & .000 & .000 & .000 \\
\hline
\end{tabular}

\begin{tabular}{lcclcc}
\multicolumn{2}{l}{ Table 2. Distributions of participants' } & demographical features. \\
\hline 1-Gender & $\mathrm{n}$ & $\%$ & 4-Marital Satus & $\mathrm{n}$ & $\%$ \\
\hline Male & 119 & 62.3 & Married & 114 & 59.7 \\
Female & 72 & 37.7 & Single & 77 & 40.3 \\
2-Assigned School Type & $\mathrm{n}$ & $\%$ & 5-Education Background & $\mathrm{n}$ & $\%$ \\
Secondary School & 117 & 61.3 & Lisans & 161 & 84.3 \\
High School & 74 & 38.7 & Master & 30 & 15.7 \\
3-Assigned Region & $\mathrm{n}$ & $\%$ & 6-Seniority & $\mathrm{n}$ & $\%$ \\
Marmara Region & 42 & 22.0 & 1-5 Years & 86 & 45.0 \\
Central Anatolia Region & 31 & 16.2 & 6-10 Years & 41 & 21.5 \\
East Anatolia Region & 26 & 13.6 & 11-15 Years & 26 & 13.6 \\
Eagean Region & 27 & 14.1 & 21-25 Years & 21 & 11.0 \\
Black SeaRegion & 10 & 5.2 & 21-25 Years & 10 & 5.2 \\
Mediterranean Region & 18 & 9.4 & Over 26 Years & 7 & 3.7 \\
Southeast Anatolian Region & 37 & 19.4 & Total & 191 & 100.0 \\
\hline
\end{tabular}


According to Table 2, from the physical education and sport teachers participating in the research; $59.7 \%$ (114) are males. $40.3 \%$ (72) are females. $84.3 \%$ (161) of the teachers work at secondary schools. $15.7 \%$ (30) of them work at high schools. As geographical regions, of the teachers $22 \%$ (42) work in the Marmara Region, 19.4\% (37) in the Southeast Anatolian Region, 16.2\% (31) in the Central Anatolian Region, 14.1\% (27) in the Aegean Region, \%13.6 (26) in the East Anatolian Region, 9.4\% (18) in the Mediterranean Region, 5.2\% (10) in the Black Sea Region as well. Of the teachers, $59.7 \%$ (114) are married, 40.3\% (77) are single. Given education backgrounds, 84.3 (161) of the teachers are bachelors, $15.7 \%$ (30) of them are masters. The teachers mostly have 1-5 years of service as $45.0 \%$ (86), 6-10 years of service as $21.5 \%$ (41), $11-15$ years of service as $13.6 \%$ (26). $16-20$ years of service as $11.0 \%$ (21). $21-25$ years of service as $5.2 \%(10)$ and 26 and over years of service as $3.7 \%$ (7) 26 .

When looked at Table 3, the general averages of the physical education and sport teachers' organizational democracy perceptions were (3.70 \pm $0.80)$, the average points were given to the response "Agree", thus, the teachers had positive perceptions about organizational democracy but the teachers' perceptions were not at a high level. Among the subdimensions, the physical education and sport teachers' organizational democracy perceptions were the highest in the "accountability" sub-dimension (3.95 \pm 1.26), the lowest in the "Justice" subdimension (3.44 \pm 0.67$)$. Considering the averages, the physical education and sport teachers' organizational justice perceptions are respectively determined by accountability, equality, transparency, participationcriticism and justice sub-dimensions at best.

When Table 4 was analyzed; the physical education and sport teachers' organizational democracy perceptions did not differ in all subdimensions in statistically significant ways in accordance with gender, assigned school type, marital status and education background variables ( $>$ > .05).

When Table 5 was examined. the difference was statistically significant in the "ParticipationCriticism" and "Equality" sub-dimensions of the physical education and sport teachers' organizational democracy perceptions in accordance with assigned geographical region as a result of Kruskall Wallis-H test $(p>0.05)$ but the point mean ranks of organizational democracy perceptions in the "Transparency, Justice and Accountability" subdimensions were significant $(\mathrm{p}<0.05)$.

In the years of service variable, the differences were not found to be statistically significant in mean ranks of the points in "Participation-Criticism". Transparency. Justice and Equality" sub-dimensions in the physical education and sport teachers' organizational democracy perceptions $(p>0.05)$ but in the "Accountability" sub-dimension the point mean ranks of organizational democracy perceptions were found to be statistically significant $(p<0.05)$. The complementary comperative techniques were used to determine which groups the significant differences result fom as a result of Kruskall Wallis-H Test. With this aim, Mann Whitney-U test was applied for pair comparions since there was no special test technique (Table 6 and 7).

Table 3. Descriptive statistical results regarding physical education and sport teachers' organizational democracy perceptions.

\begin{tabular}{lcccc}
\hline Sub-Dimensions / Total & Mean & SD & Min. & Max. \\
\hline Participation-Criticism & 3.64 & 1.01 & 8.00 & 40.00 \\
Transparency & 3.72 & 0.68 & 6.00 & 12.00 \\
Justice & 3.44 & 0.67 & 5.00 & 25.00 \\
Equality & 3.84 & 0.37 & 12.00 & 30.00 \\
Accountability & 3.95 & 1.26 & 3.00 & 15.00 \\
Total & 3.70 & 0.80 & 28.00 & 140.00 \\
\hline
\end{tabular}


Table 4. Mann Whitney-U Test results of physical education and sport teachers' organizational democracy perceptions in accordance with gender, assigned school type, marital satus and education background variables.

\begin{tabular}{|c|c|c|c|c|c|c|}
\hline Participation-Criticism & Group & $\mathrm{N}$ & Mean Rank & Sum of Rank & $\mathrm{U}$ & $\mathrm{p}$ \\
\hline \multirow[t]{2}{*}{ Gender } & Male & 119 & 95.94 & 11417.00 & 4277.000 & .985 \\
\hline & Female & 72 & 96.10 & 6919.00 & & \\
\hline \multirow[t]{2}{*}{ School Type } & Secondary School & 117 & 90.84 & 10628.50 & 3725.500 & .103 \\
\hline & High School & 74 & 104.16 & 7707.50 & & \\
\hline \multirow[t]{2}{*}{ Marital Status } & Married & 114 & 94.77 & 10804.00 & 4249.000 & .707 \\
\hline & Single & 77 & 97.82 & 7532.00 & & \\
\hline \multirow[t]{2}{*}{ Education Background } & Bachelor & 161 & 94.58 & 15227.50 & 2186.500 & .409 \\
\hline & Master & 30 & 103.62 & 3108.50 & & \\
\hline \multicolumn{7}{|l|}{ Transparency } \\
\hline \multirow[t]{2}{*}{ Gender } & Male & 119 & 95.60 & 11376.00 & 4236.000 & .844 \\
\hline & Female & 72 & 96.67 & 6960.00 & & \\
\hline \multirow[t]{2}{*}{ School Type } & Secondary School & 117 & 95.96 & 11227.00 & 4324.000 & .984 \\
\hline & High School & 74 & 96.07 & 7109.00 & & \\
\hline \multirow[t]{2}{*}{ Marital Status } & Married & 114 & 92.62 & 10558.50 & 4003.500 & .118 \\
\hline & Single & 77 & 101.01 & 7777.50 & & \\
\hline \multirow[t]{2}{*}{ Education Background } & Bachelor & 161 & 97.43 & 15685.50 & 2185.500 & .210 \\
\hline & Master & 30 & 88.35 & 2650.50 & & \\
\hline \multicolumn{7}{|l|}{ Justice } \\
\hline \multirow[t]{2}{*}{ Gender } & Male & 119 & 97.85 & 11644.50 & 4063.500 & .366 \\
\hline & Female & 72 & 92.94 & 6691.50 & & \\
\hline \multirow[t]{2}{*}{ School Type } & Secondary School & 117 & 92.55 & 10828.00 & 3925.000 & .099 \\
\hline & High School & 74 & 101.46 & 7508.00 & & \\
\hline \multirow[t]{2}{*}{ Marital Status } & Married & 114 & 94.95 & 10824.00 & 4269.000 & .627 \\
\hline & Single & 77 & 97.56 & 7512.00 & & \\
\hline \multirow[t]{2}{*}{ Education Background } & Bachelor & 161 & 95.98 & 15452.50 & 2411.500 & .985 \\
\hline & Master & 30 & 96.12 & 2883.50 & & \\
\hline \multicolumn{7}{|l|}{ Equality } \\
\hline \multirow[t]{2}{*}{ Gender } & Male & 119 & 96.70 & 11507.50 & 4200.500 & .751 \\
\hline & Female & 72 & 94.84 & 6828.50 & & \\
\hline \multirow[t]{2}{*}{ School Type } & Secondary School & 117 & 94.82 & 11093.50 & 4190.500 & .601 \\
\hline & High School & 74 & 97.87 & 7242.50 & & \\
\hline \multirow[t]{2}{*}{ Marital Status } & Married & 114 & 91.49 & 10429.50 & 3874.500 & .053 \\
\hline & Single & 77 & 102.68 & 7906.50 & & \\
\hline \multirow[t]{2}{*}{ Education Background } & Bachelor & 161 & 97.42 & 15685.00 & 2186.000 & .247 \\
\hline & Master & 30 & 88.37 & 2651.00 & & \\
\hline \multicolumn{7}{|l|}{ Accountability } \\
\hline \multirow[t]{2}{*}{ Gender } & Male & 119 & 95.58 & 11373.50 & 4233.500 & .840 \\
\hline & Female & 72 & 96.70 & 6962.50 & & \\
\hline \multirow[t]{2}{*}{ School Type } & Secondary School & 117 & 95.42 & 11164.50 & 4261.500 & .788 \\
\hline & High School & 74 & 96.91 & 7171.50 & & \\
\hline \multirow[t]{2}{*}{ Marital Status } & Married & 114 & 93.16 & 10620.50 & 4065.500 & .201 \\
\hline & Single & 77 & 100.20 & 7715.50 & & \\
\hline Education Background & Bachelor & 161 & 95.48 & 15371.50 & 2354.500 & .747 \\
\hline & Master & 30 & 98.82 & 2964.50 & & \\
\hline
\end{tabular}


Table 5. Kruskall Wallis-H Test results of physical education and sport teachers' organizational democracy perceptions in accordance with assigned geographical region, marital satus and years of service variables.

\begin{tabular}{|c|c|c|c|c|c|c|}
\hline Participation-Criticism & Group & $\mathrm{N}$ & Mean Rank & $\mathrm{df}$ & $\mathrm{X}^{2}$ & $\mathrm{p}$ \\
\hline \multirow[t]{7}{*}{ Assigned Geopraphical Region } & Marmara Region & 42 & 96.20 & & & \\
\hline & Central Anatolia Region & 31 & 94.76 & & & \\
\hline & East Anatolia Region & 26 & 99.00 & & & \\
\hline & Eagean Region & 27 & 103.15 & 6 & 5.587 & .471 \\
\hline & Black SeaRegion & 10 & 60.05 & & & \\
\hline & Mediterranean Region & 18 & 89.36 & & & \\
\hline & Southeast Anatolian Region & 37 & 102.43 & & & \\
\hline \multirow[t]{6}{*}{ Years of Service } & $1-5$ Years & 86 & 96.82 & & & \\
\hline & 6-10 Years & 41 & 96.02 & & & \\
\hline & 11-15 Years & 26 & 99.81 & & & \\
\hline & 21-25 Years & 21 & 71.02 & 5 & 6.924 & .226 \\
\hline & 21-25 Years & 10 & 118.25 & & & \\
\hline & Over 26 Years & 7 & 114.79 & & & \\
\hline \multicolumn{7}{|l|}{ Transparency } \\
\hline \multirow[t]{7}{*}{ Assigned Geopraphical Region } & Marmara Region & 42 & 89.69 & & & \\
\hline & Central Anatolia Region & 31 & 91.61 & & & \\
\hline & East Anatolia Region & 26 & 93.83 & & & \\
\hline & Eagean Region & 27 & 112.50 & 6 & 15.763 & $.015^{*}$ \\
\hline & Black SeaRegion & 10 & 73.60 & & & \\
\hline & Mediterranean Region & 18 & 86.44 & & & \\
\hline & Southeast Anatolian Region & 37 & 107.03 & & & \\
\hline \multirow[t]{6}{*}{ Years of Service } & 1-5 Years & 86 & 102.22 & & & \\
\hline & 6-10 Years & 41 & 90.24 & & & \\
\hline & 11-15 Years & 26 & 93.44 & & & \\
\hline & 21-25 Years & 21 & 80.57 & 5 & 7.899 & .162 \\
\hline & 21-25 Years & 10 & 103.70 & & & \\
\hline & Over 26 Years & 7 & 98.14 & & & \\
\hline \multicolumn{7}{|l|}{ Justice } \\
\hline \multirow[t]{7}{*}{ Assigned Geopraphical Region } & Marmara Region & 42 & 90.43 & & & \\
\hline & Central Anatolia Region & 31 & 104.23 & & & \\
\hline & East Anatolia Region & 26 & 90.58 & & & \\
\hline & Eagean Region & 27 & 108.50 & 6 & 14.678 & $.023^{*}$ \\
\hline & Black SeaRegion & 10 & 70.90 & & & \\
\hline & Mediterranean Region & 18 & 83.28 & & & \\
\hline & Southeast Anatolian Region & 37 & 103.09 & & & \\
\hline \multirow[t]{6}{*}{ Years of Service } & $1-5$ Years & 86 & 98.74 & & & \\
\hline & 6-10 Years & 41 & 98.60 & & & \\
\hline & $11-15$ Years & 26 & 96.94 & & & \\
\hline & 21-25 Years & 21 & 77.10 & 5 & 6.552 & .256 \\
\hline & 21-25 Years & 10 & 100.50 & & & \\
\hline & Over 26 Years & 7 & 93.86 & & & \\
\hline \multicolumn{7}{|l|}{ Equality } \\
\hline \multirow[t]{7}{*}{ Assigned Geopraphical Region } & Marmara Region & 42 & 91.99 & & & \\
\hline & Central Anatolia Region & 31 & 99.58 & & & \\
\hline & East Anatolia Region & 26 & 95.17 & & & \\
\hline & Eagean Region & 27 & 102.70 & 6 & 10.187 & .117 \\
\hline & Black SeaRegion & 10 & 65.00 & & & \\
\hline & Mediterranean Region & 18 & 89.14 & & & \\
\hline & Southeast Anatolian Region & 37 & 104.96 & & & \\
\hline \multirow[t]{6}{*}{ Years of Service } & $1-5$ Years & 86 & 104.13 & & & \\
\hline & 6-10 Years & 41 & 91.62 & & & \\
\hline & 11-15 Years & 26 & 95.46 & & & \\
\hline & 21-25 Years & 21 & 73.79 & 5 & 11.319 & $.045^{*}$ \\
\hline & 21-25 Years & 10 & 98.40 & & & \\
\hline & Over 26 Years & 7 & 86.93 & & & \\
\hline Accountability & & & & & & \\
\hline Assigned Geopraphical Region & Marmara Region & 42 & 88.15 & & & \\
\hline & Central Anatolia Region & 31 & 99.85 & & & \\
\hline & East Anatolia Region & 26 & 92.83 & & & \\
\hline & Eagean Region & 27 & 109.20 & 6 & 15.896 & $.014^{*}$ \\
\hline & Black SeaRegion & 10 & 62.55 & & & \\
\hline & Mediterranean Region & 18 & 93.25 & & & \\
\hline & Southeast Anatolian Region & 37 & 104.65 & & & \\
\hline Years of Service & $1-5$ Years & 86 & 100.07 & & & \\
\hline & 6-10 Years & 41 & 93.85 & & & \\
\hline & 11-15 Years & 26 & 93.71 & & & 110 \\
\hline & 21-25 Years & 21 & 77.00 & 5 & 8.769 & .119 \\
\hline & 21-25 Years & 10 & 112.50 & & & \\
\hline & Over 26 Years & 7 & 100.50 & & & \\
\hline
\end{tabular}


Table 6. Mann Whitney-U Test results to determine in which groups points of organizational democracy perception scale in transparency, justice and accountability subdimensions vary in accordance with assigned geographical region variable.

\begin{tabular}{|c|c|c|c|c|c|}
\hline Dimension & Groups & $\mathrm{N}$ & Mean Rank & $\mathrm{U}$ & $\mathrm{p}$ \\
\hline \multirow{14}{*}{ Transparency } & Marmara R. & 42 & 36.68 & \multirow{2}{*}{637.500} & \multirow[b]{2}{*}{$.028^{*}$} \\
\hline & Southeast Anatolian R. & 37 & 43.77 & & \\
\hline & Marmara R. & 42 & 31.79 & \multirow{2}{*}{432.000} & \multirow{2}{*}{$.007^{*}$} \\
\hline & Eagean R. & 27 & 40.00 & & \\
\hline & Central Anatolia B. & 31 & 26.45 & \multirow{2}{*}{324.000} & \multirow{2}{*}{$.009^{*}$} \\
\hline & Eagean B. & 27 & 33.00 & & \\
\hline & Central Anatolia R. & 31 & 31.44 & \multirow{2}{*}{478.500} & \multirow{2}{*}{$.047^{*}$} \\
\hline & Southeast Anatolian R. & 37 & 37.07 & & \\
\hline & East Anatolia R. & 26 & 24.40 & \multirow{2}{*}{283.500} & \multirow{2}{*}{$.018^{*}$} \\
\hline & Eagean R & 27 & 29.50 & & \\
\hline & Eagean B. & 27 & 25.50 & \multirow{2}{*}{175.500} & \multirow{2}{*}{$.004^{*}$} \\
\hline & Mediterranean R. & 18 & 19.25 & & \\
\hline & Mediterranean R. & 18 & 24.03 & \multirow{2}{*}{261.500} & \multirow{2}{*}{$.027^{*}$} \\
\hline & Southeast Anatolian R. & 37 & 29.93 & & \\
\hline \multirow{8}{*}{ Justice } & Marmara R. & 42 & 32.43 & \multirow{2}{*}{459.000} & \multirow{2}{*}{$.030^{*}$} \\
\hline & Eagean R. & 27 & 39.00 & & \\
\hline & East Anatolia R. & 26 & 24.40 & \multirow{2}{*}{283.500} & \multirow{2}{*}{$.018^{*}$} \\
\hline & Eagean R. & 27 & 29.50 & & \\
\hline & Eagean R. & 27 & 25.50 & \multirow{2}{*}{175.500} & \multirow{2}{*}{$.004^{*}$} \\
\hline & Mediterranean R. & 18 & 19.25 & & \\
\hline & Mediterranean R. & 18 & 23.94 & \multirow{2}{*}{260.000} & \multirow{2}{*}{$.024^{*}$} \\
\hline & Southeast Anatolian R. & 37 & 29.97 & & \\
\hline \multirow{6}{*}{ Accountability } & Marmara R. & 42 & 31.94 & \multirow{2}{*}{438.500} & \multirow{2}{*}{$.017^{*}$} \\
\hline & Eagean R. & 27 & 39.76 & & \\
\hline & Eagean R. & 27 & 21.39 & \multirow{3}{*}{70.500} & \multirow{3}{*}{$.026^{*}$} \\
\hline & Black SeaR. & 10 & 12.55 & & \\
\hline & Black SeaR. & 10 & 15.95 & & \\
\hline & Southeast Anatolian R. & 37 & 26.18 & 104.500 & $.035^{*}$ \\
\hline
\end{tabular}

Table 7. Mann Whitney-U Test results to determine in which groups points of organizational democracy perception scale vary in accordance with years of service variable.

\begin{tabular}{lllcccc}
\hline Dimension & Variable & Groups & N & Mean Ranks & U & $\mathrm{p}$ \\
\hline Accountability & Service of Years & 1-5 Years & 86 & 56.51 & 687.500 & $.015^{*}$ \\
& & 21-25 Years & 21 & 43.74 & & \\
\hline${ }^{*} p<.05$ & & & & &
\end{tabular}

When Table 6 was assessed, as a result of Mann Whitney U Test for the "Transparency" subdimension of organizational democracy scale, the difference associated with geographical regions was in favour of dutied ones in the Southeast Anatolian Region between Marmara. Mediterranean and Central Anatolian Regions and Southeast Anatolian Region, in favour of dutied ones in the Aegean Region between Marmara. Central Anatolian. Eastern Anatolia. Mediterranean Regions and Aegean Region $(\mathrm{p}<.05)$. The significant difference in the sub-dimension "Justice" was in favour of dutied ones in the Aegean Region between Marmara. Eastern Anatolia. Mediterranean Regions and Aegean Region, was in favour of dutied ones in the Southeast Anatolian Region between Mediterranean and Southeast Anatolian Regions $(\mathrm{p}<.05)$. The significant difference in the sub-dimension "Accountability" was in favour of dutied teachers in the Aegean Region between Marmara. Black Sea and Aegean Regions, was in favour of dutied teachers in the Southeast Anatolian Region between Black Sea and Southeast Anatolian Regions ( $\mathrm{p}<.05)$.

When Table 7 was examined, as a result of Mann Whitney U Test fort he "Accountability" subdimension of organizational democracy scale. the difference from the seniority variable was in favour of the teachers having 1-5 years of service between the teachers with 1-5 years of service and the teachers with 21-25 years of service $(\mathrm{p}<.05)$. The difference between the mean ranks of other groups not shown at table was regarded to be insignificant ( $p>05)$. In the light of these findings, the new teachers' 
information and perception levels can be said to be high about accountability in management.

\section{DISCUSSION}

This study analyzed the physical education and sport teachers' perceptions about organizational democracy and reached at these results. It was seen that the teachers had positive perceptions associated with organizational democracy but these perceptions were not at a high level, the highest level of organizational democracy perceptions was included in "accountability", the lowest one was in the subdimension "justice".

It was determined that the physical education and sport teachers' organizational democracy perceptions did not significantly differ in all subdimensions in accordance with gender, assigned school type, marital status and education background variables but there were significant differences in terms of organizational democracy perceptions in the sub-dimensions of transparency, justice and accountability in accordance with assigned geographical region and only in the accountability sub-dimension in accordance with seniority situations. In terms of the transparency and justice sub-dimensions, in the Aegean and Southeast Anatolian Regions, in terms of the accountability subdimension, in the Aegean Region dutied teachers had higher organizational democracy perceptions than teachers assigned in other regions. In accordance with seniority situation, the organizational democracy perceptions were higher in the accountability sub-dimension among the teachers having 1-5 years of seniority than the teachers having 21-25 years of seniority. New teachers are considered to have high information and perception levels about accountability in management.

When the body of literature about the research issue was studied; some separate researches were found about democratical structure of teachers' school environment, organization culture, and organizational opposition, organizational confidence, leadership features of school managers, participation-criticism, justice, transparency, equality and accountability sub-dimensions while any direct researches were not found about the physical education and sport teachers' organizational democracy perceptions. In Şeker and Topsakal's research (47) titled with Adoption and Practice Levels of Organizational Democracy in Primary-Secondary Schools in Accordance with Administrator and Teacher Perceptions, administrators and teachers adopted organizational democracy inprimarysecondary schools but they had views about its practice at a moderate level. Acar et al. (1) studied the relation between school administrators' ethical leadership behaviours and physical education teachers' organizational justice perceptions and concluded that when school administrators' behaviours increased in harmonisation with ethical principles, teachers' organizational justice sense arose as well.

Özan et al. (37) suggested that school administrators' democratic attitudes and behaviours positively affected teachers' motivation. Özdemir (39) stated that administrator support and common behaviouralism in schools encouraged teachers to show organizational citizenship behaviours. Karadağ et al. (30) claimed that there was a significant relation between school administrators' perceived democratic attitude levels and teachers' democratic values. Also. Karaevli and Levent (31) determined that transparency contributed to teachers' professional development in school management. Furthermore, it had positive reflections in order to have healthy functioning of mentorship activities, effective communication and sustainable confidence environment. These findings support our study results.

Another finding of the study was that the teachers' perceptions were low in the justice subdimension of organizational democracy rather than other sub-dimensions. Titrek (51) claimed that workers' views about organizational justice level at schools in Turkey simply focused on relations between administrators and workers. Çelik (13) stated that teachers' general justice perceptions were generally high but lower than school administrators. Titrek (51) concluded that organizational justice level was generally positive at primary-secondary schools in Turkey but some behaviours possibly affected organizational justice perceptions. Sarı and Sadık (45) studied about candidate teachers' democracy perceptions and said that democracy-based metaphors developed by the teachers mostly were classified into equality, independence and multivocality themes.

The other finding from this research was that the teachers' views regarding the sub-dimensions of organizational democracy did not differ in gender, marital status, education background and assigned school type (secondary school-high school) variables. Similar results were observed in some researches. Ünlü et al. (53) claimed that the teachers' perceptions 
about organizational justice were at a high level, the teachers' organizational justice perceptions did not differ in gender but assigned school type (primary school, secondary school, high school). Karadağ et al. (30) reported that the relation between democratic attitude levels perceived by teachers and democratic values adopted by teachers did not differ in teachers' gender. Bahadir and Certel (6) stated that any statistically significant difference was not found in organizational silence in accordance with physical education teachers' gender when they researched on physical education teachers' organizational silence and organizational commitments. Some different researches showed that organizational justice perceptions did not vary in gender $(13,17,19,23,32)$.

Our research found that teachers' organizational democracy perception did not vary in marital status and education background variables, some studies partly support this one. Çelik (13) put forward that teachers' distributive and operational justice perceptions did not vary in marital status and education background variables. Kılıç and Demirtaş (34) also suggested that any significant difference was not seen between teachers' organizational justice perceptions in terms of education level. Also. Şeker \& Topsakal (47) reported that teachers' views did not change in adoption and practice levels of organizational democracy in terms of education background. Teachers' organizational democracy perceptions did not differ in education background, which was indicated by similar researches on teachers' democratic attitudes and behaviours $(25,42,44)$.

Our study also found that organizational democracy perceptions lowered in the accountability dimension when teachers' length of service went up. Argon et al. (3) observed that the standardized dimension of accountability scale in Turkish national education system was lower among the teachers having 11-15 years of service than the teachers having 6-10 and 16 and over years of service and this situation was related with professional burnout. Hence years of service are expected to rise as well as age. When descriptions and features about the accountability and organizational justice subdimensions of organizational democracy are dealt together, there is a positively high relation between school administrators' accountability and organizational justice, when school administrators' accountability improves, perceptions about organizational justice will have tendencies to develop (29).
Teachers' organizational accountability perceptions based on seniority are also related with organizational justice perceptions. Ertürk's research (19) showed that teacher perceptions regarding organizational justice reduced when age went up. Çelik (13) stated that organizational justice perception which shows increase with age, reduces towards retirement age as well. Ünlü et al. (53 claimed that justice perception lowered when age group increased. Ünlü et al. (53) said that this difference may result from that a teacher starting profession new

Another finding from the research, the assigned teachers' organizational democracy perceptions were higher at the transparency and justice subdimensions in Aegean and Southeast Anatolian Regions, at the accountability sub-dimension in Aegean Region. Titrek (51) informed that organizational justice perceptions of the teachers in western regions and metropolitan city schools were more positive than organizational justice perceptions of the teachers dutied at schools in eastern regions. Güçlü and Kılınç (26) researched on the accountability levels of school administrators in accordance with the primary-secondary school teachers and concluded that the teachers complied with behaviours under responsibility, clearity and responsiveness dimensions of accountability among the school administrators at a medium level. Koçak et al. (35)

Unfair practices affect teachers' performance, job satisfaction and dependence on school in negative ways at most (40). When teachers are involved in decision making process in school organization. Their job satisfaction increases. So their continuation for their relevant organization may be developed, and they are considered as parts of organization and their efficiency may be developed as well (14). Within this study, these suggestions were obtained; teachers must be encouraged for more effective participation in management in education institutions. Management practices must be more transparent. School administrators must display effective leadership characteristics in order to create a democratical school structure and they must make effort to create an organizational environment based on confidence, justice, equality and accountability in school.

\section{REFERENCES}

1. Acar G. Kaya M. Şahin. MY. School administrator's ethical leadership behavior effects on physical education teachers 
organizational justice level. Turkish Journal of Sport and Exercise, 2012; 14(3): 51- 58.

2. Akman N. Kamu yönetiminde hesap verebilirlik. necmiakman.blogspot.com.tr/2015/01/necmi-akman-giris20.html. 2015. Erişim Tarihi: 14.07.2017

3. Argon T. Uylas SD. Yerlikaya S. Perceptions of teachers related accountability practices in Turkish national education sistem and organizational cynicism. International Online Journal of Educational Sciences, 2015; 7(2): 204-219.

4. Ataç LO. Köse S. The relationship between organizational democracy and organizational dissent: A Research on white collar workers. Istanbul University Journal of the School of Business, 2017; 46(1): 117-132.

5. Avc1 N. Eğitim yönetiminde hesap verilebilirlik gencburokrat.com/kose-yazisi/40/egitim-yonetiminde-hesapverilebilirlik.html. 2015. Erişim Tarihi: 25.06.2017

6. Bahadır Z. Certel Z. Investigation of organizational silence and organizational commitment of physical education teachers. Ahi Evran Üniversitesi Kırşehir Eğitim Fakültesi Dergisi (KEFAD), 2017; 7(1): 135-146.

7. Bakan İ. Kara E. Güler B. The effects of organizational democracy perception on employees' intrapreneurship performance: An empirical in hotel firms in Marmaris. HAK-İş Uluslararas Emek ve Toplum Dergisi, 2017; 6(14): 115-138.

8. Başaran İE. Örgütsel davranış. Ankara Üniversitesi Eğitim Fakültesi Yayınları, Ankara, 1982.

9. Benligiray S. İnsan kaynakları yönetimi. Anadolu Üniversitesi, Eskişehir, 2004

10. Bozkurt T. Çalışma ilişkilerinin evrimi. Beta Yayınları, İstanbul, 2011.

11. Coşan PE. Gülova AA. Organizational democracy. Yönetim ve Ekonomi, 2014; 21(2): 231-248.

12. Crane A. Matten D. What is stakeholder democracy? Perspectives and issues, business ethics. A Europan Review, 2005; 14(1): 6-13.

13. Çelik OT. The relationship between school managers' and tteachers' perception of organizational justice and job satisfaction. Unpublished Doctoral Thesis, Selçuk University Institute of Educational Sciences, Konya, 2012.

14. Demirtaş Z. Alanoğlu M. The relationship between participation in decisionmaking of teachers and job satisfaction. Ahi Evran Üniversitesi Kırşehir Eğitim Fakültesi Dergisi (KEFAD), 2015; 16(2): 83-100.

15. DiPaola MF. Tarter CJ. Hoy WK. Measuring organizational citizenship of schools: The OCB Scale. (Eds.: Hoy. W. and Miskel. C.). Educational Leadership and Reform, Greenwich, CN: Information Age Publishing, 2005; 319-341.

16. Dive B. The accountable leader: Developing effective leadership through managerial accountability. Kogan Page Limited, London, 2008.

17. Doğan A. The impact of organizational justice on organizational commitment in primary schools (The sample of Elazi ̌̆ province). Unpublished Master's Thesis, Firat University. Institute of Social Sciences, Elazığ, 2008.

18. Erkal PC. Research on organizational democracy with regards the public and private labour. Unpublshed doctoral thesis.
Celal Bayar University, Institute of Social Sciences, Manisa, 2012.

19. Ertürk E. The relationship between perception of organizational justice and teachers? Organizational commitment in primary and secondary schools. Unpublished Master's Thesis, Mehmet Akif Ersoy University, Institute of Social Sciences, Burdur, 2011.

20. Eryılmaz B. Biricikoğlu H. Accountability and ethics in public Administration. Turkish Journal of Business Ethics, 2011; 4(7): 19-45.

21. Geçkil T. Tikici M. Örgütsel demokrasi ile örgütsel vatandaşlık davranışları arasındaki ilişki. 22. Ulusal Yönetim ve Organizasyon Kongresi, 22-24 Mayıs 2014, Konya.

22. Geçkil T. Tikici M. A study on developing the organizational democracy Scale. Amme İdaresi Dergisi, 2015; 48(4): 41-78.

23. Girgin S. Bayraktar HV. Study of perceived organizational justice of administrators by teachers. International Periodical for the Languages. Literature and History of Turkish or Turkic, 2017; 12(4): 217-238.

24. Gömleksiz MN. Çetintaş S. Democratic attitudes of prospective teachers (Case of Firat. Dicle. 7 Aralık. Cumhuriyet and Erzincan Universities). Dicle University Journal of Ziya Gökalp Facultiy of Education, 2011; 17: 1-14.

25. Gözütok D. Öğretmenlerin demokratik tutumları. Türk Demokrasi Vakfi, Ankara, 1995.

26. Güçlü N. Kılınç AÇ. İlköğretim okulu öğretmenlerinin görüşlerine göre okul yöneticilerinin hesap verebilirlik düzeyleri. e-Journal of New World Sciences Academy, 2011; 6(3): 2110-2122.

27. Harrison JS. Freeman E. Special topic: Democracy in and around organizations. Academy of Management Executive, 2004; 18: 49-53.

28. Johnson P. Whence democracy? A review and critique of the conceptual dimensions and implications of the business case for organizational democracy. Organization, 2006; 13(2): 245274.

29. Kalman M. Gedikoğlu T. An investigation of the relationship between school administrators' accountability and organizational justice. H. U. Journal of Education, 2014; 29(2): 115-128.

30. Karadağ E. Baloğlu N. Yalçınkayalar P. A study on the relation between democratic attitudes of primary school administrators perceived by the teachers and democratic values of the teachers. Journal of Values Education, 2006; 4(12): 65-82.

31. Karaevli Ö. Levent F. Investigation of effect of transparency in school administration on teachers who are in different career phases. Journal of Educational Sciences, 2014; 40: 89-108.

32. Karaman P. Örgütsel adalet algısı ile tükenmişlik arasındaki ilişkinin incelenmesine yönelik öğretmenler üzerinde bir uygulama. Yayımlanmamış Yüksek lisans Tezi, Yıldız Teknik Üniversitesi, İstanbul, 2009.

33. Kesen M. Investigating the effects of organizational democracy and organizational 1dentification on job satisfaction: A field study on retail industry. IIB International Refereed Academic Social Sciences Journal, 2015; 6(19): 61-89. 
34. Kılıç Y. Demirtaş Z. The perceptıons of organızatıonal justıce of secondary teachers. Journal of Research in Education and Teaching, 2014; 4(2): 46-58.

35. Koçak E. Turan S. Aydoğdu E. Öğretmenlerin yetki devri. Otonomi ve hesap verebilirliklerine ilişkin görüşlerinin incelenmesi. Journal of Education and Humanities: Teori ve Uygulama, 2012; 3(5): 117-148.

36. Lansbury DR. Workplace democrarcy and the global financial crisis. Journal of Industrial Relations, 2009; 51: 1-22.

37. Özan MB. Türkoğlu AZ. Şener G. The effect of democratic attitude and behaviors of school managers on the motivation of teachers. Firat University Journal of Social Science, 2010; 20(1): 275-294.

38. Özdemir A. The relationship of perceived superior support and individualism collectivism with organizational citizenship behaviors in primary schools. Educational Administration: Theory and Practice, 2010; 1(1): 93-112.

39. Özdemir M. Eğitim örgütlerinde insan kaynakları yönetimi. Anı Yayıncılık, Ankara, 2014.

40. Özgan H. Bozbayındır F. Unfair applications and their effects in schools. Dicle Üniversitesi Ziya Gökalp Eğitim Fakültesi Dergisi, 2011; 16: 66-85.

41. Özpolat A. Bir toplumsal değişme paradigması olarak demokrasinin eğitime yansımaları: Demokratik eğitim. Millî Eğitim, 2010; 185: 365-381.

42. Peker R. The assesment of the class teacher's democratic attitudes and attitudes regarding childrens rights (Case Manisa). Yayımlanmamış Yüksek lisans Tezi. Mehmet Akif Ersoy Üniversity. Social Sciences Institute, Burdur, 2012.

43. Sadykova G. Tutar H. A study on the relationship between organizational democracy and organizational dissent. The Journal of Business Science, 2014; 2(1): 1-16.

44. Saraçoğlu SA. İlke E. Varol SR. A comparative research on the democratic attitudes of the teachers and the prospective teachers. EducationalSciences: Theory and Practice, 2004; 4(2) 356-364.
45. Sarı M. Sadık F. Democracy perceptions of teacher candidates (Çukurova University sample). Uluslararası Eğitim Programları ve Öğretim Çalışmaları Dergisi, 2001; 1(2): 67-82.

46. Smith MP. Barriers to organizational democracy in public administration. Administration and Society, 2016; 8(3): 275317.

47. Şeker G. Topsakal C. The level of ability to adopt and apply organizational democracy to primary schools according to perceptions of teachers and administrators. Educational Sciences: Theory \& Practice, 2011; 11(3): 1203-1227.

48. Şengül R. Yazkan E. Yönetişim modeli olarak kalkınma ajansları. Küresel esintiler ve yerel etkiler sarmalında Türk kamu yönetimi. (Edt: A. Yılmaz ve Y. Bozkurt). Gazi Kitabevi. Ankara, 2007.

49. Şişman M. Güleş H. Dönmez A. Qualifications framework for a democratic school culture. Uşak Üniversity Journal of Social Sciences, 2010; (3)1: 167-182.

50. Taşçı D. Koç U. The relationship between organizational citizenship behaviors and organizational learning values: An ampirical research on academic personnel. Anadolu University Journal of Social Sciences, 2007; 7(2): 373-382.

51. Titrek $O$. The level of organizational justice in schools according to school types. Uluslararası İnsan Bilimleri Dergisi, 2009; 6(2): 551-573.

52. Ulutaş M. Örgütsel demokrasi: Katılımcı yönetim. Nüve Kültür Merkezi Yayınları, Konya, 2011.

53. Ünlü Y. Hamedoğlu MA. The relationship between perceived organizatinal justice and organizational silence level of teachers. Sakarya University Journal of Education, 2015; 5(2): 140-157.

54. Yazdani N. Organizational democracy and organizational structure link: Role of strategic leadership enviromental uncertainly. Research Journal of the Institute of Business Administration, 2010; 5(2): 51-73.

55. Y1ldırım F. The Relationship between organizational justice and lob Satisfaction. Ankara University the Journal of the Faculty of Political Sciences, 2007; 62(1). 253-278. 